\title{
Beauty in the Middle Ages: A Forgotten Transcendental?
}

\author{
Jan A. Aertsen
}

"Habent sua fata libelli" (Books have their own fates). This saying is especially applicable to the scholarly work of Umberto Eco. In the fifties he published in Italian studies of Thomas Aquinas's aesthetics and of beauty in the Middle Ages that shared the lot of so many scholarly publications: they attracted attention only in a restricted circle. But after the success of Eco's novel, The Name of the Rose, his earlier studies too have gained a large audience among publishers and the public. In 1986, Art and Beauty in the Middle Ages appeared, followed in 1988 by the English translation of Eco's dissertation, The Aesthetics of Thomas Aquinas. ${ }^{1}$

There is no reason to be unhappy about this development. Eco's studies are among the best that have appeared in this field. They distinguish themselves from many other studies by their concern for

This paper was presented as the Cardinal Mercier lecture at the Catholic University of Louvain on 22 February 1990.

I. Umberto Eco, "Sviluppo dell'estetica medievale," in Momenti e problemi di storia dell'estetica 1: Dall'antichità classica al barocco (Milan: Marzorati, 1959), pp. 115-230, translated as Art and Beauty in the Middle Ages (New Haven and London: Yale Univ. Press, 1986); Eco, Il problema estetico in san Tommaso, 2d ed. (Milan: Valentino Bompiani, 1970; 1st ed. 1956), translated as The Aesthetics of Thomas Aquinas (Cambridge, Mass.: Harvard Univ. Press, 1988). 
the historical context of the medieval doctrine of beauty and for the links between medieval aesthetics and the realities of the age. In both books Eco pays much attention to a question he calls "one of the main problems of Scholastic aesthetics," namely, "the problem of integrating, on the metaphysical level, beauty with other forms of value." It was not by accident that in this period, in contrast to the tendency in our times, the problem of integration was philosophically prominent. An integrated sensibility was characteristic of the aesthetic experience of the medievals. Life appeared to them as something wholly integrated, in the sense of a culture whose value systems are related to one another. ${ }^{2}$

The strategy that scholastic philosophy developed for the integration of values involved the doctrine of the transcendentia. Transcendentals are concomitant conditions of being. They thus transcend the particular modes of being, which Aristotle called the "categories." Transcendentals, such as one, true, and good, are properties of being as such. Medieval philosophy aspired to establish that the values of unity, truth, and goodness are not actualized sporadically and accidentally but adhere rather to being as coextensive metaphysical properties. Every being is one, true, and good. Transcendentals are convertible with being and with one another. Yet this doctrine stresses at the same time that transcendentals are not identical with one another. They differ conceptually (ratione). The notion of being is different from that of unity, truth, or goodness. Transcendentals refer to the same reality but do so in different ways. Each transcendental is conceptually distinctive. ${ }^{3}$ So Eco observes that the doctrine of transcendentals tried to allow both for the autonomy of values and for their place within a unitary vision of the transcendental aspects of being. 4

The basic question now is whether there is a distinct place for beauty in the doctrine of transcendentals. ${ }^{5}$ If the beautiful is con-

2. Eco, Art and Beauty, pp. 15-16.

3. For a general discussion of the doctrine of transcendentals, see Jan A. Aertsen, "Die Transzendentalienlehre bei Thomas von Aquin in ihren historischen Hintergründen und philosophischen Motiven," in Thomas von Aquin: Sein Leben, sein Werk und seine Zeit in der neuesten Forschung, edited by A. Zimmermann, Miscellanea Mediaevalia 19 (Berlin and New York: De Gruyter, 1988), pp. 82-102.

4. Eco, Art and Beauty, pp. 16, 19.

5. Eco deals with this question in Art and Beauty, pp. 17-27; and in Aesthetics, pp. $20-48$. 
sidered to be a transcendental, the fundamental consequence is that "it acquires a metaphysical worth, an unchanging objectivity, and an extension which is universal." 6 The beauty of the universe would be founded on a metaphysical certainty and not on mere poetic sentiment. But for the medievals is beauty a transcendental property of being? I want to examine this question by focusing on Thomas Aquinas's thought, which also occupies a prominent place in Eco's studies.

\section{THOMAS ON BEAUTY}

A fact that has often been noted but still needs to be mentioned again and again is that one cannot speak properly of "the aesthetics of Thomas Aquinas." Nowhere in his writings does he present a systematic treatise on this theme or engage in an extensive discussion of the beautiful. We find in his work only scattered remarks about the subject. These remarks concern especially the proper ratio of the beautiful. Thomas even provides a definition of his own: "Those things are called beautiful which please when they are seen" ("quae visa placent"). ${ }^{7}$ Two things are expressed in this definition. The beautiful is that which pleases and delights; it is that in which the appetite comes to rest. The beautiful is ordered to appetite and is thereby set in close relation to the good, for Thomas counts the good as the proper object of the appetite. Yet at the same time the definition relates the beautiful to seeing, by which is not exclusively meant knowing by sense. Beauty is the object of contemplation.

Eco advances an objection to Thomas's definition. "The phrase ... visa placent ... is a disturbing intrusion into the whole question." It introduces a subjective condition for beauty ("when they are seen"), and thus points "to a denial of its transcendental status." 8 But is this conclusion correct? To answer this question we must notice the peculiar character of Thomas's definition. This character may be elucidated through a comparison with the definition of the good provided by Aristotle at the beginning of the Nicomachean Ethics and adopted by Thomas : "The good is that which all things desire" ("quod omnia appetunt"). Thomas points out in his commentary that this phrase does not indicate the essence of the good. It is rather a definition per

6. Eco, Aesthetics, p. 22.

7. Summa theol. 1.5.4 ad 1.

8. Eco, Aesthetics, p. 39. 
posteriora: the good is determined through its proper effect. ${ }^{9}$ The definition accordingly does not mean that something is good because it is desired but rather the reverse: that something is desired because it is good. The cause, the essence of the good itself, is manifested by the effect. The relation to the appetitive power does not constitute the good, but rather follows upon the essence of the good. Now something similar is the case in Thomas's definition of beauty. Indeed, I think it likely that Thomas framed this definition on analogy to that of the good. "Something is not beautiful because we love it; rather, it is loved by us because it is beautiful and good." 10 The phrase quae visa placent is a definition a posteriori. It does not introduce a subjective condition of the beautiful so much as it defines the beautiful from its proper effect. "That which pleases when it is seen" does not say what the beautiful itself is.

What then is the essence of the beautiful? In a classic passage in the Summa theologiae (1.39.8), Thomas states that three things are required for beauty: integritas, or perfectio, that is, "integrity," or "completeness"; debita proportio, or consonantia, that is, "due proportion," or "harmony"; and claritas, that is, "clarity," "brightness," or "splendor." Thomas provides no explanation of this notion but only an example ("whence things are called beautiful which have a bright color"). However, this triad does not seem to have an absolute force or canonical meaning. In other places he mentions only two conditions: "clarity" and "due proportion," so he says, go together in the ratio of beauty. ${ }^{11}$ In all texts Thomas is satisfied just to enumerate the conditions of beauty. He puts them side by side but does not indicate their mutual relationship in such a way that the a posteriori definition of the beautiful becomes clear from it.

If the beautiful is a transcendental, then it must participate in the two features of transcendentals: because of their universal extension they are really identical, but they differ from one another conceptually. Thomas's work contains passages, as we have seen, about the proper ratio of the beautiful. But with respect to the other

9. Super Ethic. 1.1.9.

ı. Super De div. nomin. 4.10 (no. 439): "Non enim ideo aliquid est pulchrum quia nos illud amamus, sed quia est pulchrum et bonum ideo amatur a nobis."

I I. Summa theol. 2-2.145.2: "Ad rationem pulchri, sive decori, concurrit et claritas et debita proportio." Compare 2-2.180.2 ad 3. 
feature of transcendentals, their convertibility with being, the situation is different. No texts affirm that the beautiful is a universal property of being or express explicitly the transcendentality of beauty. Yet most modern scholars hold that the beautiful in Thomas does have a transcendental status.

A strong impulse to this trend in research stemmed from Maritain's Art and Scholasticism. He argued that the beautiful belongs to the order of transcendentals. "It is in fact the splendour of all the transcendentals together." 12 Umberto Eco too is of the opinion that the beautiful is a transcendental, albeit implicitly so. He admits that "Aquinas's text is filled with uncertainties and hesitations."13 Such reserve and caution are absent in three German monographs devoted to beauty in Thomas. Francis J. Kovach arrives at the conclusion that the beautiful is "the richest, the most noble, and the most comprehensive of all transcendentals"; it is "the only transcendental that includes all the other transcendentals." 14 In the judgment of Winfried Czapiewski, the beautiful is the original unity of the true and the good. ${ }^{15}$ Günther Pöltner, finally, regards beauty as "the origin of thought in Thomas Aquinas"; the beautiful is the unity of the transcendental determinations of being. 16

The outcome of the studies in question confronts us with a striking paradox. The discussion of the beautiful occupies a marginal place in Thomas's work. Nowhere does he himself say that beauty is a transcendental property. Gilson has spoken in this regard of a "forgotten transcendental." 17 But in the Thomas research of the last decades,

12. Jacques Maritain, Art and Scholasticism (London: Sheed and Ward, 1939), p. 172, n. 63b. An elaboration of Maritain's view can be found in G. B. Phelan, "The Concept of Beauty in St. Thomas Aquinas," in Selected Papers (Toronto: Pontifical Institute of Mediaeval Studies, 1967), pp. 155-180.

13. Eco, Aesthetics, pp. 46-47.

14. Francis J. Kovach, Die Ästhetik des Thomas von Aquin (Berlin and New York: De Gruyter, 1961), p. 214; Kovach, "The Transcendentality of Beauty in Thomas Aquinas," in Die Metaphysik im Mittelalter, edited by P. Wilpert, Miscellanea Mediaevalia 2 (Berlin: De Gruyter, 1963), p. 392.

15. Winfried Czapiewski, Das Schöne bei Thomas von Aquin (Freiburg: Herder, 1964).

I6. Günther Pöltner, Schönheit: Eine Untersuchung zum Ursprung des Denkens bei Thomas von Aquin (Vienna: Herder, 1978), p. 76.

17. E. Gilson, "The Forgotten Transcendental: Pulchrum," in Elements of Christian Philosophy (New York: Doubleday, 1960), pp. 159-163. 
more attention has been devoted to the beautiful than to any other transcendental. No other of them has such an extensive literature. ${ }^{18}$ Moreover, it is suggested that the beautiful has a central role in Thomas's thought, since it would be the synthesis and unity of all transcendentals.

Now that the English version of Eco's studies has drawn attention once again to the aesthetics of Thomas Aquinas, there is every reason, I believe, to review the thesis of the transcendentality of the beautiful and to take stock of the discussion about it. From what follows it will become clear that in my view the arguments that have been advanced for the status of the beautiful as a distinct transcendental are unsound for philosophical and historical reasons.

\section{THE POSSIBLE SYSTEMATIC PLACE OF THE BEAUTIFUL}

The only writing in which Thomas presents a systematic exposition of the transcendentals is De veritate. He does so here even twice, namely, in q. 1 (concerning truth) and in q. 21 (concerning goodness). Although there are differences between the two texts, these need not engage us now. As the point of departure for my analysis, I take De veritate 1.1 , because it is the more complete account.

There are in Thomas's exposition three points having significance for the discussion of the beautiful. The first point may seem selfevident, but its import will become clear in the sections to come. It concerns the ontological perspective within which Thomas places the doctrine of transcendentals. In the first article of De veritate he posits that our concepts must be reduced to "first," immediate insights. This first, the inception of thought, is being. "That which the intellect first conceives, as best known, and into which it resolves [resolvit] all its concepts, is being [ens]." Thomas presents no argument for this priority. He does do so in Summa theologiae 1.5.2, where he raises the question "Whether the good is prior in concept [secundum rationem] to

I8. See, in addition to the studies mentioned above, A. A. Maurer, About Beauty: A Thomistic Interpretation (Houston: Center for Thomistic Studies, Univ. of St. Thomas, 1983); Mark D. Jordan, "The Evidence of the Transcendentals and the Place of Beauty in Thomas Aquinas," International Philosophical Quarterly 29 (1989): 393-407. 
being." There he says again that the first thing conceived by the intellect is being, but he also gives a reason: "For everything is knowable only insofar as it is in act." Hence being is the first intelligible and is prior in concept to the good. The priority of being is based on its actuality.

If being is the first known, then it follows that all other concepts arise by addition to being. How is this possible? Nothing can be added to being that is not itself a being; outside of being there is nothing. Other concepts can therefore only add something to being in the sense that they express a mode of being that the term "being" itself does not yet express. The transcendentia are terms that make explicit, not some special, categorial mode of being, but a general mode consequent on every being ("modus generalis consequens omne ens"). ${ }^{19}$ From this the ontological import of the doctrine of transcendentals becomes clear. Each of them expresses a general mode of being. If the beautiful is a transcendental, it must present a further explication of being as being.

A second point deserving of attention is connected with a constantly recurring theme in Eco's studies. In his view, Thomas's definition of the beautiful introduces a subjective element ("a reference to a knowing subject") that is hardly compatible with the transcendentality of the beautiful. ${ }^{20}$ Now we have already noticed the peculiar character of this definition. But from De veritate 1.1 it also appears that the opposition suggested by Eco is alien to Thomas. For Thomas's exposition makes clear that transcendentals can be relational without thereby being subjective.

He divides the transcendentals into two groups, since the general mode of being expressed by them pertains to every being either in itself (in se) or in relation to another (in ordine ad aliud). To the first group of transcendentals belong "thing" (res) and "one." With respect to the relational transcendentals Thomas presents a further division. The relation of one being to another can be considered in the first place according to their division. This is expressed by the name "something" (aliquid), which according to Thomas says literally "some other thing" (aliud quid). But there is besides that a more positive relational mode of being, namely, the "conformity" (convenientia) of

19. This term is not used in De veritate 1.1, but it does occur in 21.3.

20. Eco, Aesthetics, pp. 118-119. 
one being to another. The condition for such a relation is something whose nature it is to accord with every being. Such is the soul which, as Aristotle said (On the Soul 3.8.431b21), "is in a certain sense all things." In the soul there are a cognitive power and an appetitive power. The conformity of being to the appetite is expressed by the name "good," for the good is defined as "that which all things desire." The conformity to the intellect is expressed by the name "true." 21 In Thomas's determination of the true and the good, the special place of the spiritual being amidst the other beings is recognized. The anima is the being that can accord with every being. Humankind is marked, so one might say, by a transcendental openness. Thomas's reflection on the transcendentals reveals an anthropocentrism.

The third point of importance is a simple observation. In De veritate 1.1, Thomas presents six transcendentals: ens, res, unum, aliquid, verum, and bonum. In 21.1, he names four; res and aliquid are not mentioned. In neither of the two texts, however, does he affirm that the beautiful is a transcendental. ${ }^{22}$ This observation gives rise to two questions. If the beautiful is a transcendental for Thomas, as modern scholars suggest, why is it not named? And if the beautiful is a transcendental, what might be its systematic place in the list of transcendentals?

Eco takes hardly any notice of these two questions, but the other writers mentioned do. For Maritain neither question constitutes a serious problem. The "classic table" in De veritate 1.1 , so he says, "does not exhaust all transcendental values." The reason that the beautiful is not included is "that it can be reduced to one of them," namely, to the good. ${ }^{23}$ This argument is not very convincing. If the beautiful is really a transcendental, then it must make explicit a gen-

2r. De verit. 1.1: "In anima autem est vis cognitiva et appetitiva; convenientiam ergo entis ad appetitum exprimit hoc nomen 'bonum', unde in principio Ethicorum dicitur quod 'bonum est quod omnia appetunt,' convenientiam vero entis ad intellectum exprimit hoc nomen 'verum'."

22. The only place in De veritate where the beautiful comes up for discussion is $22.1 \mathrm{ad}$ 12. There it is subsumed under the notion of good: "Ex hoc enim ipso quod aliquid appetit bonum, appetit simul pulchrum et pacem: pulchrum quidem, in quantum est in seipso modificatum et specificatum, quod in ratione boni includitur. . . . Unde quicumque appetit bonum, appetit hoc ipso pulchrum."

23. Maritain, Art and Scholasticism, p. 172 , n. $63 \mathrm{~b}$. 
eral mode of being and add a value to being conceptually that cannot be reduced to another transcendental.

Kovach recognizes that Thomas in De veritate 1.1 has elaborated a "complete system." The reason for the absence of the beautiful in the list must be that Thomas arrived at insight into the transcendentality of the beautiful only after De veritate. Hence Kovach's thesis is that Thomas's thought exhibits an "immanent development" on this point. ${ }^{24} \mathrm{~A}$ decisive role in this development was played by Thomas's commentary on the De divinis nominibus of pseudo-Dionysius the Areopagite. In this commentary, which can be dated to 1265-1267, about ten years after De veritate, Thomas comes to see that the beautiful is a transcendental. We shall postpone discussion of Kovach's thesis to the following section, in which we analyze Thomas's commentary.

As to the systematic place of the beautiful, Kovach holds that it belongs at the end of the list of transcendentals. The beautiful is the final integration of the transcendentals; it has a synthetic function. For the uniqueness of the beautiful is that it is the relation of being to the two faculties of the soul, the cognitive and the appetitive, these faculties taken not separately but jointly. ${ }^{25}$ Yet it is doubtful whether this synthetic view of the beautiful fits into the doctrine of transcendentals. Transcendentals do not stand apart from each other, but are marked by a progressive explication of being. There is an ordo of the transcendentals: being is the first, next comes the one, then the true, and finally the good. In this order what is later includes conceptually what is earlier: the good presupposes the true, i.e., the intelligibility of that which is ("bonum praesupponit verum"). ${ }^{26}$ The determination good includes that of being, one, and true. ${ }^{27}$ From a systematic point of view there is no room in Thomas's doctrine for a unique transcendental, the beautiful, that would synthesize the other transcendentals. Transcendentals have as such a real unity, which is founded in the

24. Kovach, Ästhetik, pp. 75-76, 183.

25. Kovach, Ästhetik, pp. 212-214; "The Transcendentality of Beauty," pp. 391392.

26. De verit. 21.3: "Et ita plura includit in se ratio boni quam ratio veri, et se habet quodammodo per additionem ad illa; et sic bonum praesupponit verum. . . . Unde istorum nominum transcendentium talis est ordo, si secundum se considerentur, quod post ens est unum, deinde verum, deinde post verum bonum."

27. De verit. 21.6 ad 2 . 
first, being, and a conceptual order, which is completed in the ultimate, the good.

Kovach is not alone in setting out to determine the place of the beautiful on the basis of Thomas's definition of it, which relates to both the cognitive and the appetitive. That is apparent in Czapiewski's approach. To him the beautiful is not the transcendental that is the last in the list but the one that precedes the true and the good. The beautiful must be taken to be the one relation of being to the two spiritual faculties of the soul, the intellect and the will. The beautiful is the original unity from which the true and the good unfold. Yet this unity of the true and the good remains hidden; it cannot be adequately conceived. It can only be approached from the different points of view of the true and the good. For the finite spirit realizes itself, precisely because of its finiteness, through the duality of intellect and will, to which the duality of the true and the good corresponds. That is why the beautiful cannot be given a place in the list of transcendentals. ${ }^{28}$

Czapiewski's solution is Kovach's in reverse. The beautiful is not the final synthesis of the transcendentals but the original unity of truth and goodness. Yet this solution gives rise to an objection similar to the one evoked by Kovach's. The idea that the unity of the true and the good is based on an earlier transcendental-Czapiewski speaks of an "Urmodus"29_-is inconsistent with the order of transcendentals stated by Thomas. In this order the later includes the earlier conceptually, and not the earlier the later.

The essence of Czapiewski's interpretation is in fact that he thinks that Thomas's exposition in De veritate concerning the positive relational transcendentals needs completion. The triad soul-intellectwill posited by Thomas would require a corresponding triad of beautiful-true-good. As the duality of intellect and will, which is characteristic of the finite spirit, is rooted in the unity of the spirit, so likewise the true and the good unfold from a unity, and this unity is the beautiful. But Thomas's train of thought is an essentially different one and, so I would add, a more satisfactory one from a transcendental point of view. He posits a relationship of correspondence between being-true-good on the one hand and soul-intellect-will on the

28. Czapiewski, Das Schöne bei Thomas, pp. 121-131.

29. Czapiewski, p. 140. 
other hand. He justifies this correspondence from what we called earlier the "transcendental openness" of the spirit. The soul is the being that can accord with every being - the soul is "in a certain sense all things," has an infiniteness. ${ }^{30}$ Now there is in every spiritual nature, not only in the finite spirit, an intellect and a will. ${ }^{31}$ The acts of both faculties manifest the infiniteness of the spirit, for their formal objects are the true and the good, respectively, which are convertible with being. ${ }^{32}$ The emphasis in Thomas's exposition is not on the finiteness of the spirit but on its intentional infiniteness. There is in his doctrine no need whatsoever for a hidden transcendental that would be the unitary center of the true and the good. The attempts of various writers to find a distinct place for beauty as a transcendental must be regarded as having failed.

\section{THE BEAUTIFUL IN DE DIVINIS NOMINIBUS OF PSEUDO-DIONYSIUS}

The most important authority for Thomas's concept of beauty is pseudo-Dionysius the Areopagite. Now Kovach suggested, as we have seen, that Thomas's thought on beauty shows development. Not until his commentary on pseudo-Dionysius's De divinis nominibus would he have arrived at insight into the transcendentality of the beautiful. ${ }^{33}$ But what clues does Dionysius's text offer for the transcendental status of the beautiful? Is there evidence in Thomas's commentary to support Kovach's view?

Dionysius's intention in this treatise is to elucidate the names attributed in Scripture to God that manifest God's causality

30. Compare Super Sent. 3.27.1.4: "Res immateriales infinitatem habent quodammodo, quia sunt quodammodo omnia."

31. Compare Summa theol. 1.19.1: "Dicendum in Deo voluntatem esse, sicut et in eo est intellectus: voluntas enim intellectum consequitur."

32. Summa theol. 1.54.2: "Secunda autem actio [that is, an immanent action] de sui ratione habet infinitatem vel simpliciter, vel secundum quid. Simpliciter quidem, sicut intelligere, cujus objectum est verum; et velle, cujus objectum est bonum; quorum utrumque convertitur cum ente; et ita intelligere et velle, quantum est de se, habent se ad omnia."

33. See also Francis J. Kovach, "Der Einfluss der Schrift des Pseudo-Dionysius 'De divinis nominibus' auf die Schönheitsphilosophie des Thomas von Aquin," Archiv für Geschichte der Philosophie 63 (1981): 150-166. 
with respect to creatures. The primary of these divine names for $\mathrm{Di}$ onysius is the Good, that is, the name ascribed in Neoplatonism to the first principle. "The sacred writers have preeminently set apart from all other names for the supradivine God the name 'Good.' "34 Good is the first, prior even to Being, because this name manifests most fully the processions of the creatures from God.

The consequence of Dionysius's intention is that his emphasis lies on the transcendence of the Good and the other names. The (Neo)platonic way of thought is eminently suited to this transcendence, and Dionysius's treatment of the divine names is accordingly strongly inspired by it. His way of speaking about God is Platonic, as Thomas in his Commentary observes: the divine good is "beyond" all that exists, is "the good itself," "the per se good," the supergood. ${ }^{35}$ Dionysius's perspective is therefore different from that of Thomas's doctrine of the transcendentia. The good is for Dionysius the first, while from the transcendental point of view being is the first and the good the ultimate. Dionysius's concern is the transcendence of the divine, not the transcendentality of the most general determinations of being. ${ }^{36}$

One of the most remarkable aspects of Thomas's commentary on De divinis nominibus is that he makes an attempt to connect the different approaches. In the prologue Thomas wants to justify Dionysius's Platonic way of speaking of God. He describes the Platonists as wanting to reduce all that is composed to simple and abstract (abstracta) principles. Thus they posit the existence of separate Forms of things ("Human being per se," "Animal per se"). They apply this abstract approach not only to the species of natural things but also to that which is most common (maxime communia), namely, good, one, and being. They hold that there is a first, which is the essence of goodness, of unity, and of being, a principle that we, Thomas says, call "God." The other

34. De divinis nominibus 4 (PG 3:693B). Thomas explains Dionysius's intention in Super De div. nomin. 3.1 (no. 227): "Intendit enim in hoc libro agere de divinis nominibus manifestantibus processiones creaturarum a Deo, secundum quod est causa rerum. Id autem quod habet rationem causae, primo et universaliter est bonum."

35. Super De div. nomin. prooemium.

36. See my essay "Good as Transcendental and the Transcendence of the Good," in Being and Goodness: The Concept of the Good in Metaphysics and Philosophical Theology, edited by Scott MacDonald (Ithaca, N.Y.: Cornell University Press, 1991), pp. 79-102. 
things are called "good," "one," and "being" because of their derivation from the first principle.

In the continuation of the prologue Thomas rejects the first application of the Platonic method, subscribing to Aristotle's criticism: there are no separate, subsisting Forms of natural things. But with regard to the first principle of things, Thomas recognizes the legitimacy of the Platonic approach. ${ }^{37} \mathrm{He}$ advances no argument for the validity of the Platonic method, but this can lie in nothing else than in its application to that which is most common. For Thomas, the Platonic reduction to abstract principles is only justified at the level of the maxime communia, that is, at the transcendental level. In this way he establishes a connection between the transcendental approach and the transcendent approach of the Platonists. This connection is possible because there is a causal relation between the first "separated" principle and the transcendentals. The maxime communia have to be reduced to God as the most universal cause. What belongs to these maxime communia Thomas enumerates: good, one, and being. He does not, however, name the beautiful, although that cannot of course serve as a decisive argument against the transcendentality of the beautiful.

Dionysius deals with the divine name the Beautiful in De divinis nominibus 4. The context of this exposition is not without importance for its interpretation. Chapter 4, the most extensive one in the whole work, treats successively the Good, Light, Beauty, Love, Ecstasy, and Zeal, to close with a treatise on evil. Thomas would not be Thomas if he did not endeavor to discover a connection in this diversity of names and themes. In his first lectio of chapter 4 , he indicates what this connection is: all these subjects are directly connected with the Good, the primary name. Evil is dealt with because evil is the opposite of the good, and opposites belong to the same consideration. Love and the related notions are dealt with because the act is known through the object, and the good is the proper object of love. Thomas explains the reason that chapter 4 also deals with

37. Super De div. nomin. prooemium: "Haec igitur Platonicorum ratio fidei non consonat nec veritati, quantum ad hoc quod continet de speciebus naturalibus separatis, sed quantum ad id quod dicebant de primo rerum principio, verissima est eorum opinio." 
beauty: "Because the good is that which all things desire, there belongs to the ratio of the good everything that possesses of itself the ratio of desirability. Of that nature are light and the beautiful." 38

Thomas's structuring of chapter 4 brings out the close connection between the good and the beautiful. In this way he expresses aptly the idea dominating Dionysius's exposition of the beautiful. For Dionysius concludes, as we shall see, that the good and the beautiful are identical. The Areopagite is in this respect a typical representative of Greek thought, for in it the beautiful and the good are brought together in a single notion, the kalokagathia. ${ }^{39}$

The identity Dionysius posits between the good and the beautiful is something that must always be kept in mind in the interpretation of his statements about the beautiful. When he says, for example, "There is no being that does not participate in the good and the beautiful," 40 this seems to suggest that the beautiful is a transcendental. Every being is in some way beautiful. Kovach takes Dionysius's statement, which Thomas in his commentary cites verbatim, in this sense. But this interpretation overlooks a decisive point. Dionysius does not mean to say that the beautiful is a property next to and distinct from the good. And this is precisely the point at issue with respect to the transcendentality of the beautiful.

Dionysius's discussion of the beautiful is focused, in keeping with the general intention of De divinis nominibus, on the question of how the names Beauty and Beautiful are attributed to God. Two elements in his account deserve attention.

First, Dionysius expresses what he understands by beauty. God is called Beauty because, so he says, God confers beauty on all things, is the cause of the consonance and clarity in all things. Dionysius's conception of beauty combines the two streams of Greek aesthetics:

38. Super De div. nomin. 4.1 (no. 266): "Cum bonum sit quod omnia appetunt, quaecumque de se important appetibilis rationem, ad rationem boni pertinere videntur; huiusmodi autem sunt lumen et pulchrum."

39. See, for this notion, Historisches Wörterbuch der Philosophie 4 (Darmstadt: Wissenschaftliche Buchgesellschaft, 1976), pp. 681-684. Thomas himself points to the relationship between the Greek names for "the good" (kalos) and "the beautiful" (kallos) in Super Sent. 1.31.2.1 ob. 4.

40. De divinis nominibus 4 (PG 3:704B). Compare Super De div. nomin. 4.5 (no. $355)$. 
the older Pythagorean, Platonic one with the Neoplatonic one. According to the older Greek thinkers beauty is based on a relationship of parts and harmony. But Plotinus had argued that beauty also occurs in simple things: the sun and the evening star are beautiful not because of their proportion but because of their brilliance. Light, therefore, is no less a determining factor of beauty than harmony is. ${ }^{41}$ Thomas observes in his commentary that the ratio of beauty consists in these two characteristics. ${ }^{42} \mathrm{We}$ saw above that Thomas sometimes names three conditions of beauty-perfectio, proportio or consonantia, and claritas-but sometimes only the last two. Now it becomes clear that the dual formula goes back to the authority of Dionysius. Thomas always refers to this text when he restricts the features of the beautiful to consonantia and claritas. 43

What deserves attention in the second place is Dionysius's description of God as "the most beautiful." 44 Here again it becomes apparent how strongly the Areopagite is inspired by Platonism. For he employs verbatim in this passage the formulations that are used in Plato's Symposium (211A-B) to describe the Idea of the Beautiful. God is enduringly and uniformly beautiful, while the beauty of earthly things is mutable and corruptible. The divine beauty does not wax and wane. God is not beautiful in one respect and ugly in another. Beauty is not God's in a limited way. God is beautiful through and in Godself. Plato's description is eminently suited to show the uniqueness and transcendence of the divine beauty. It is in this that Dionysius is interested. It is therefore somewhat surprising that Czapiewski considers Thomas's commentary on this passage, in which Aquinas adds nothing essential to Dionysius's words, to be the (only) text that undeniably implies the transcendentality of the beautiful. 45

In the Symposium it is said that Eros is love for the beautiful, which is at once love for the good, since the good is also

4I. W. Tatarkiewicz, History of Aesthetics 2: Medieval Aesthetics (The Hague and Paris: Mouton, 1970), pp. 30, 15-16.

42. Super De div. nomin. 4.5 (no. 339).

43. See, for instance, Summa theol. 2-2.145.2: "Sicut accipi potest ex verbis Dionysii, 4 cap. De divinis nominibus, ad rationem pulchri . . . concurrit et claritas et debita proportio."

44. Super De div. nomin. 4.5 (nos. 345-347).

45. Czapiewski, Das Schöne bei Thomas, pp. 29-31. 
beautiful (201C). Dionysius concurs with this idea. He concludes that the good and the beautiful are identical. His arguments are that all things desire the beautiful and the good as a cause in every one of its ways (thus the Beautiful-and-Good is the efficient, exemplary, and final cause of all things) and, further, that there is "nothing that does not participate in the beautiful and the good." But Thomas modifies Dionysius's conclusion and adds an observation of his own, which is worth citing in its entirety:

Although the beautiful and the good are the same in reality [idem subiecto] - because both clarity and consonance are contained in the notion of the good-nevertheless, they differ in concept. For the beautiful adds to the good an ordering to the power that is able to know that a thing is of such a kind. 46

In this passage Thomas clearly goes beyond Dionysius. He introduces a new element, although he does not elaborate it. He asserts that there is a conceptual difference between the beautiful and the good. The beautiful adds to the good a relation to the cognitive power. By the same token it is striking that Thomas formulates the identity of, and the difference between, the beautiful and the good in terms that he usually employs in connection with transcendentals. Eco stresses this point: "These two features-being identical in the subject, but differing ratione - are features appropriate to transcendental attributes; this, for example, is the case with the good and the true." 47 Does not Thomas therefore suggest in this passage that the beautiful is a transcendental?

Yet there is a fundamental objection to be raised against the interpretation that Thomas at this place in his commentary teaches the transcendentality of the beautiful. The outcome of our analysis of Thomas's exposition in De veritate 1.1 was that his doctrine of transcendentals is set in an ontological perspective. Transcendentals express a general mode of being, they add something conceptually to being. So true adds to being a relation to the intellect; good adds the notion of the appetible or desirable. ${ }^{48}$ Here Thomas does not say, however, that the beautiful expresses a general mode of being, nor does he speak of an addition to being. The beautiful adds something to

46. Super De div. nomin. 4.5 (no. 356).

47. Eco, Aesthetics, p. 31.

48. Summa theol. 1.16.3: "Sicut bonum addit rationem appetibilis super ens, ita et verum comparationem ad intellectum." 
the good; it expresses a mode of the good. This idea is strengthened further by the fact that in the passage cited clarity and consonanceof which Thomas had said earlier in his commentary that they form the proper ratio of the beautiful-are contained in the notion of the good ("sub ratione boni"). Eco too must acknowledge that "this explanation seems rather to assimilate the beautiful into the good than to identify both of them with being." 49

Our conclusion must be that Thomas in his commentary does not teach that the beautiful expresses a general mode of being, on the basis of which it would have to be incorporated in the list as a new transcendental. He does distance himself from Dionysius by claiming that the beautiful adds a relation to the cognitive power, a new element that will still have to engage our attention. But what the beautiful adds is an addition to the good, not to being. For it is the true that adds to being the relation to knowledge. Thomas follows Dionysius in seeing the beautiful in connection with the good.

The identity of the good and the beautiful is affirmed repeatedly in the continuation of chapter 4 . It may suffice to refer to two characteristic passages. When, after his treatment of the Beautiful, Dionysius proceeds to the discussion of Love, he begins his exposition with the statement: "The beautiful and the good are for all things desirable and lovable" (amabile). ${ }^{50}$ Both the beautiful and the good are the object of love. It is this statement that Thomas cites at many places in his work. The second passage occurs at the end of chapter 4 . There Dionysius endeavors to determine the various types of evil from their opposite, the good. Thomas summarizes the line of argument as follows: Dionysius first establishes the ratio of the good in general, and then what follows upon the general ratio of the good. Beauty belongs to the latter, for "the beautiful is convertible with the good" ("pulchrum convertitur cum bono"). ${ }^{51}$ The beautiful is a property of the good as good.

\section{TWO TEXTS IN THE SUMMA THEOLOGIAE}

The outcome of the analysis of Thomas's commentary on Dionysius is confirmed by the fact that there is no breakthrough to the

49. Eco, Aesthetics, p. 31. 400).

50. De divinis nominibus 4 (PG 3:708A). Compare Super De div. nomin. 4.9 (no.

51. Super De div. nomin. 4.22 (nos. 589-590). 
beautiful as transcendental in Thomas's writings after this commentary. In his Summa theologiae, Thomas deals with the good (1.5-6), the one (1.11), and the true (1.16), but he devotes no separate quaestio to the beautiful. When we gather together Thomas's statements in the Summa about the status of the beautiful, the entire file turns out to consist of just two texts. It is striking that in both texts the beautiful comes up only in objections, not in the corpus of the article, and that the context of the discussion is always the good.

The first relevant text is Summa 1.5.4, where Thomas raises the question "Whether the good has the character of a final cause." The first objection refers to the opening sentence of Dionysius's exposition on beauty in De divinis nominibus: "The Good is praised as beautiful." Now the beautiful has the character of a formal cause. Therefore the good must have the same character. In his reply to this objection, Thomas first emphasizes the real identity of the beautiful and the good. They are the same in subject because they are based on the same reality, namely, the form. Yet they differ conceptually (ratione). Proper to the good is that it relates to the appetite, for the good is what all things desire; thus the good has the character of an end. The beautiful, on the other hand, relates to the cognitive power ("respicit vim cognoscitivam"). Thomas then presents his definition of the beautiful, which we have already discussed: "For those things are called beautiful which please when they are seen." Now because cognition is effected through assimilation, and likeness (similitudo) concerns the form, the beautiful properly pertains to the notion of a formal cause.

The second text is Summa 1-2.27.1, "Whether the good is the only cause of love." In the third objection, Thomas cites Dionysius's statement in chapter 4 of De divinis nominibus that the beautiful as well as the good is lovable for all things. The good is thus not the only cause of love. In his reply to this objection, Thomas once again elaborates the conceptual difference between the good and the beautiful. The ratio of the good is "that in which the appetite comes to rest." It pertains to the notion of the beautiful that the appetite comes to rest in the sight or knowledge of it ("in ejus aspectu seu cognitione"). Thus it appears that the beautiful adds to the good an ordering to the cognitive power. Good refers to that which simply pleases the appetite ("simpliciter complacet appetitui"). Beautiful refers to that the apprehension of which pleases ("id cujus ipsa apprehensio placet").

The two texts in fact present a further elaboration of Thomas's 
observation in his commentary on Dionysius that the beautiful adds to the good a relation to cognitive power. The novelty of medieval, as compared to Greek, thought about beauty is this emphasis on the relation of the beautiful to knowledge (cognitio, visio, aspectus, apprehensio). The beautiful is quae visa placent. But in both texts the transcendental status of the beautiful remains unclear.

Eco is of the opinion that "these two passages seem definitive, though only implicitly so. They are definitive because . . . they establish that beauty is a constant property of all being. . . . That is, beauty is identified with being simply as being." 52 But this "definitive" conclusion can certainly not be inferred from the two texts. The beautiful is not identified with being but with the good. Thomas's formulations suggest rather that the beautiful is a specification of the good: the good is that which simply pleases; the beautiful is that of which the apprehension pleases. It is on the basis of these phrases that Cajetan in his commentary on Summa theol. 1-2.27.1 ad 3 concludes that the beautiful is "quaedam boni species." 53

Thomas's texts offer no definite answer about the transcendentality of the beautiful. But its status can be clarified by placing both texts in a broader context and considering them in connection with other thirteenth-century expositions on the beautiful.

\section{HISTORICAL BACKGROUND}

Eco devotes much attention to the thirteenth-century discussion of the beautiful. He relies on the documentation assembled by Pouillon in an influential study. ${ }^{54}$ The historical background is indeed illuminating for the understanding of Thomas's texts, but, as it turns out, in rather a different way than Eco intends.

The doctrine of transcendentals was formed in the thirteenth century. Generally, the Summa de bono of Philip the Chancellor, written about 1230 , is regarded as the first treatise on transcendentals. In the prologue Philip establishes that being, one, true, and good are the most

52. Eco, Aesthetics, p. 36.

53. Cajetan's commentary can be found in S. Thomae Aquinatis Opera Omnia (ed. Leonina), vol. 6 (Rome, 1891), p. 192.

54. H. Pouillon, "La beauté, propriété transcendantale chez les scolastiques (1220-1270)," AHDLMA 21 (1946): 263-329. 
general things (communissima). ${ }^{55} \mathrm{He}$ does not, however, name the beautiful. Neither is the beautiful mentioned among the transcendentals in the De bono of Albert the Great (1243), which depends heavily on Philip, nor in Albert's commentary on the Sentences (1245). It is in the Summa fratris Alexandri, attributed to Alexander of Hales but in fact the work of a number of Franciscan authors, that for the first time room is made for the beautiful. The first part contains an extensive treatise on transcendental properties, written by John of La Rochelle (d. 1245). ${ }^{56}$ In discussing the good, he includes an article on the relation between the good and the beautiful. It is this exposition that deserves special attention, because it became the model for later writers.

The question is raised "Whether the good and the beautiful are the same in concept" (secundum intentionem). ${ }^{57}$ In the arguments pro, Dionysius is the authority, of course. A number of his statements identifying the beautiful with the good are cited. In the arguments contra, it is claimed that the beautiful and the good differ conceptually, because the beautiful has the character of a formal or exemplary cause, the good, on the other hand, the character of a final cause.

In his reply to the question, John of La Rochelle departs from ideas derived from Augustine. Augustine had distinguished between two kinds of good: the befitting, or virtuous (honestum), which is sought for its own sake; and the useful, which is referred to something else. Moreover, Augustine had identified honestum with intelligible beauty. ${ }^{58}$ Through this identification Augustine in fact reestablished the close tie between the moral good and the beautiful, a connection implied in the Greek term kalos but that had been lost in the Latin by Cicero's translation honestum.

55. Summa de bono prol., ed. N. Wicki (Bern: A. Francke, 1985) 2:4. Compare H. Pouillon, "Le premier traité des propriétés transcendentales: La 'Summa de bono' du Chancellier Philippe," Revue néoscolastique de philosophie 42 (1939): 40-77.

56. Alexander of Hales, Summa theologica 1.1.3 (ed. Collegii S. Bonaventurae [Quaracchi: 1924], nos. 72-110).

57. Summa theologica 1.1.3.3.2 (ed. Quaracchi no. 103, 1:162-163). Eco, Art and Beauty, p. 24, interprets secundum intentionem as "with respect to the intentionality of the percipient": "In the Summa of Alexander, the difference ratione is a difference intentione-that is, in intentionality. Beauty is thus defined in relation to the knowing subject." But this interpretation is incorrect. Intentio has in this context the same meaning as ratio; a difference intentione means a difference in concept.

58. The Summa refers to Augustine's De diversis quaest. 8330 (PL 40:19). 
On the basis of Augustine's ideas, John of La Rochelle concludes that the good, taken as honestum, is the same as the beautiful. But they differ, so he adds, conceptually. "For the beautiful is a disposition of the good insofar as it pleases the apprehension ["secundum quod est placitum apprehensioni"], whereas the good relates to the disposition insofar as it delights the affection." So they differ with respect to the notion of final cause. He goes on to add that they also differ with respect to the notions of the other causes, the efficient cause and the exemplary cause. He expounds these further differences, but the details need not concern us here. Of importance is John's reply to the objection that the beautiful has to do with the formal or exemplary cause, and the good with the final cause. He stresses that the form sometimes receives the character of end, and the end the character of form. In a similar way the beautiful assumes the character of the good, and the good that of the beautiful, although John of La Rochelle recognizes that "the primary notion of the beautiful is derived from the exemplary cause, and the primary notion of the good from the final cause." 59

When we compare the exposition in the Summa fratris Alexandri with the texts of Thomas mentioned above, we find that there are striking similarities. Thomas uses similar formulations to indicate the conceptual difference between the good and the beautiful (the beautiful is "that of which the apprehension pleases"). One also finds in him that the beautiful relates to the formal cause, the good to the final cause. Finally, we can establish that Thomas later in the Summa (22.145.2), with an appeal to Augustine, also identifies the beautiful with the honestum. ${ }^{60}$ It is true that there are differences. Thus Thomas does not connect the forma with the exemplary cause; neither does he mention additional differences between the good and the beautiful related to the notions of the efficient cause and the exemplary cause. But it is beyond doubt that the core of his line of argument goes back to the Summa attributed to Alexander of Hales.

Yet the main problem remains. What conclusion can be drawn concerning the transcendentality of the beautiful from the exposition

59. Summa theologica 1.1.3.3.2 ad 1 (ed. Quaracchi 1:163).

6o. Thomas Aquinas, Summa theol. 2-2.145.2: "Et ideo honestum est idem spirituali decori. Unde Augustinus dicit, in libro 83 Quaest.: 'Honestatem voco intelligibilem pulchritudinem, quam spiritualem nos proprie dicimus.'” 
of John of La Rochelle? Eco agrees with Pouillon that the Summa of Alexander of Hales brought about an important philosophical innovation on this point. "It decisively solved the problem of the transcendental character of beauty, and its distinction from other values." 61 But is this observation correct?

John of La Rochelle commences his treatise on transcendentals by establishing that besides being there are three common determinations, namely, the one, the true, and the good. ${ }^{62} \mathrm{He}$ discusses these one after the other, and it is within the framework of the good that he raises the question of beauty. Yet he does not add beauty to the list of transcendentals. Eco acknowledges this fact but advances in explanation "the caution and prudence with which the medievals engaged in innovation." There was, after all, a traditional number of transcendentals, and it was no small thing to alter it. "The boldness of the innovation required caution in its implementation." 63 These arguments are not very convincing. In Albert the Great, for example, there is a clear awareness that in the doctrine of transcendentals the medievals have gone beyond the Philosopher, Aristotle. ${ }^{64}$ Moreover Thomas Aquinas in De veritate 1.1 presents six transcendentals.

The picture that emerges from the exposition of John of La Rochelle is rather that the beautiful is not a new, separate transcendental, but something to be discussed within the framework of the good. This is in fact the general picture of thirteenth-century thought about the beautiful. The Summa of Alexander of Hales has determined the place of the beautiful, both in the Summa theologiae of Thomas Aquinas and in that of Albert the Great (begun after 1270). ${ }^{65}$

There is one exception to this communis opinio. The only writer in the thirteenth century who explicitly says that the beautiful is a distinct transcendental is the author of the manuscript Assisi, Biblioteca

61. Eco, Art and Beauty, p. 23.

62. Summa theologica 1.1.3.1 (ed. Quaracchi no. 73, 1:114): "Ens est primum intelligibile; primae autem entis determinationes sunt 'unum' et 'verum' et 'bonum'."

63. Eco, Aesthetics, p. 44. Compare Art and Beauty, p. 24.

64. Albert the Great, In Sent. 1.46.N.14 (ed. Borgnet 26:450): "Dicendum, quod secundum Philosophum, ante omnia sunt ens et unum. Philosophus enim non ponit, quod verum et bonum sint dispositiones generaliter concomitantes ens."

65. Albert the Great, Summa theologiae 1.6.26.2.3 (Opera Omnia, ed. Cologne 34/1:177-179): "Utrum bonum et pulchrum secundum communem intentionem sint idem vel diversa." 
Comunale 186. The authorship of this manuscript is contested; it is sometimes attributed to Bonaventure. ${ }^{66}$ It concerns an excerpt from the Summa of Alexander of Hales to which the anonymous author, probably a student, sometimes attaches his own conclusions. At the beginning of the text it is said that there are four general conditiones entis, namely, "the one, the true, the good, and the beautiful." All four add something conceptually to being: the one relates to the efficient cause; the true, to the formal cause; the good, to the final cause. The beautiful encompasses all these causes and is common to them. ${ }^{67}$ This synthetic function of the beautiful is, however, not further elaborated in the treatise. If Bonaventure was the author of the manuscript, then it is striking that in his later works he nowhere makes mention of the beautiful as transcendental and constantly restricts himself to the triad the one, the true, and the good. ${ }^{68}$ In doing so he follows the current opinion in the thirteenth century. That the beautiful is not a separate transcendental is the rule in this period. The title of Pouillon's study suggests more than it can substantiate.

\section{THE PLACE OF BEAUTY}

In the second section we came to the conclusion that the efforts of modern scholars to find a distinct place for the beautiful as a transcendental in Thomas's doctrine must be regarded as having failed. The previous section has now shown that the common opinion of the thirteenth century was that the beautiful is not a separate transcendental. What, then, was its place? Thomas offers no direct answer to this question. But we have found in his writings a number of statements that can serve as a basis for a reflection on his view. We

66. The text is edited by D. Halcour, "Tractatus de transcendentalibus entis conditionibus (Assisi, Biblioteca Comunale, Codex 186)," Franziskanische Studien 41 (1959): 41-106. The title that Halcour has given to the treatise is anachronistic. The term transcendentalis is unknown in the Middle Ages.

67. Tractatus de transcendentalibus 1.1 (ed. Halcour, p. 65): "Dicendum, quod istae conditiones fundantur supra ens, addunt enim aliquam rationem. . . . Sed pulcrum circuit omnem causam et est commune ad ista."

68. Bonaventure, Breviloquium 1.6.2 (Opera Omnia 5:215): "conditiones entis nobilissimae et generalissimae . . . hae autem sunt unum, verum, bonum." Compare Karl Peter, Die Lehre von der Schönheit nach Bonaventura (Werl: Dietrich-CoeldeVerlag, 1964), p. 135, n. 15. 
recall his definition of the beautiful and the three essential characteristics of the beautiful that he enumerates (integritas or perfectio, debita proportio or consonantia, and claritas [section 1]); his observation in the commentary on Dionysius that the good and the beautiful are really identical, but conceptually different, in the sense that the beautiful adds to the good a relation to the cognitive power (section 3); and the elaboration of this conceptual difference in the two texts from the Summa theologiae (section 4). On the basis of this material, I shall attempt to determine the place of the beautiful systematically.

"The beautiful is convertible with the good." For Thomas, following Greek thought, the place of the beautiful is the good. The mark of the good is that it is desirable. Something is desirable insofar as it is perfect. Proper to the good as good is that it is perfectum; ${ }^{69}$ it has the character of something "complete." Perfect is what attains to its end, to its proper nature. The same is denoted in a negative way by the term integrum, which expresses the removal of diminution (remotionem diminutionis). ${ }^{70}$ Now Thomas in Summa theol. 1.39.8 names as the first condition of the beautiful "integrity," or "perfection," for, so he explains, "those things which are impaired [diminuta] are by that very fact ugly." Earlier we saw that Thomas sometimes restricts the ratio of the beautiful to two characteristics. There is a historical reason for this, namely, the authority of pseudoDionysius, who mentions only proportion and clarity. But we can now also adduce a philosophical reason for the changing number. The first condition of the beautiful, perfectio, is of another kind than the other two. It is a generic condition that binds the beautiful to the good as good. The beautiful pleases because it is perfect.

Summa 1.5 treats "of the good in general." The first three articles of this question concern the convertibility of being and the good, the last three what is proper to the good. In article 5 Thomas states the ratio of the good as good, in article 6 the division of the good. Both articles are important for the beautiful.

69. Summa theol. 1.5.5: "Unumquodque dicitur bonum, inquantum est perfectum: sic est enim appetibile."

70. Super De div. nomin. 2.2 (no. 115): "Integrum autem et perfectum idem videntur esse; differunt tamen ratione: nam perfectum videtur dici aliquid in attingendo ad propriam naturam, integrum autem per remotionem diminutionis." 
The good is divided into the befitting (honestum), which is desired for its own sake; the useful (utile), which is desired as a means to something else; and the pleasing (delectabile), in which the appetite comes to rest. Thomas observes that this division properly concerns the human good. But if one considers the notion of goodness "from a higher and more universal point of view," one will find that this division properly belongs to the good so far as it is good. ${ }^{71}$ The extension of this division to the good as such is important for the beautiful because Thomas, following Alexander of Hales, identifies the beautiful with the primary good, the bonum honestum. The beautiful pleases, not because it has an instrumental function, but because it is in itself good.

In article 5 Thomas teaches that the ratio of the good as good consists in three essential features, modus (measure), species, and ordo. In his account of this Augustinian triad, the notion of "form" is central. Everything is called "good" insofar as it is perfect. The perfection of a thing comes to be realized through its form. The form itself is signified by the species, for everything is placed in its species by its form. Now the form presupposes certain things, and from the form certain things necessarily follow. The form presupposes commensuration of its principles, and this is signified by the modus. Following on form is an inclination toward the end, and this relation to something else belongs to the ordo.

If the beautiful is identical with the good, because it is perfect, then the beautiful must follow the ratio of the good as good. Indeed, some medieval writers, as in the Summa fratris Alexandri, simply identify the essence of the beautiful with Augustine's triad of the good. In Thomas too we find statements tending in that direction. "A thing is beautiful so far as it is proportioned [modificatum] and specified [specificatum] in itself, features that are included in the ratio of the good." 72 His general approach is to maintain Dionysius's conception of beauty, but he does connect the three essential constituents of the goodness of things with the characteristics belonging to the ratio of the beautiful, proportio or consonantia and claritas.

7I. Summa theol. 1.5.6: "Haec divisio videtur esse proprie boni humani. Si tamen altius et communius consideremus rationem boni, invenitur haec divisio proprie competere bono, secundum quod bonum est."

72. De verit. 22.1 ad 12 . 
Beauty as harmony can be conceived as an internal relation in a thing or as a relation of one thing to another. Thomas's standard example of the former is that a man is called beautiful by reason of the due proportio, or "commensuration," of his members. ${ }^{73}$ Thomas uses the same term "commensuration" to describe the modus, the first feature of the good, and the same example to illustrate this condition. ${ }^{74} \mathrm{He}$ relates consonantia to the ordo to something else and claims that claritas refers to the form. ${ }^{75}$ Clarity therefore corresponds to species, a term which itself has an aesthetic connotation (species sive pulchritudo) under the influence of a tradition that goes back to Augustine, as Thomas points out. ${ }^{76}$

The notion of claritas specifies wherein the aesthetic aspect of the species consists. For clarity is identified by Thomas with truth and the knowability of things. It is described as light. ${ }^{77}$ The mark of light, both physical and spiritual, is that it makes things visible. It has the property of manifestatio. "Therefore all that is manifest is called clarum." 78 Hence claritas is the property on the basis of which a thing is able to manifest and show itself. From this it follows that claritas is the feature of the beautiful that expresses what the beautiful adds to the

73. Super De div. nomin. 4.5 (no. 339); Super Sent. 1.31.2.1. Thomas frequently uses commensuratio as a synonym of proportio. See, for instance, Super De div. nomin. 4.21 (no. 554).

74. Compare Super De div. nomin. 4.22 (no. 589): "Primo accipienda est ratio boni in communi, ad quam tria pertinent: scilicet commensuratio aliquorum ex quibus aliquid componitur, ut . . . pulchritudo (est) commensuratio membrorum."

75. Super De div. nomin. 4.6 (no. 367): "Forma autem a qua dependet propria ratio rei, pertinet ad claritatem; ordo autem ad finem, ad consonantiam." Thomas, in his commentary, describes consonantia in terms of ordo. See 4.5 (no. 340): "Est autem duplex consonantia in rebus: prima quidem, secundum ordinem creaturarum ad Deum; . . . secunda autem consonantia est in rebus secundum ordinationem earum ad invicem."

76. Super Sent. 1.31.2.1: "Species, id est pulchritudo." Summa theol. 1.39.8: "Species sive pulchritudo." Thomas refers to Augustine in Resp. ad Ioann. Vercell. de art. 108, 57 (no. 884): "speciem interpretatur pulchritudinem."

77. Super Job 40: "Deus enim non habet circumdatum decorem quasi superadditum eius essentiae sed ipsa essentia eius est decor per quem intelligitur ipsa claritas sive veritas." Super Sent. 4.49.2.3 ad 7: "Claritas dei dicitur veritas suae essentiae per quam cognoscibilis est sicut sol per suam claritatem." Super Ioann. 1.11 (no. 212): "Claritas Dei non est aliud quam eius substantia: non enim est lucens per participationem luminis, sed per seipsam."

78. Super Sent. 2.13.1.2. 
good: the relation to the cognitive power. This relation specifies the place of the beautiful.

The relation to knowledge which is implied in the beautiful is not something that is foreign to the good, not something extrinsic to its concept. The order of the transcendentals is that the good presupposes the true. Appetite cannot be directed towards the good unless it is known. ${ }^{79}$ The object that moves appetite is the bonum apprehensum. From this Thomas draws in Summa 1-2.27.2after having shown in the preceding article that the good is the proper cause of love-the conclusion that love requires some knowledge of the good. "For this reason the contemplation of spiritual beauty or goodness is the principle of spiritual love." 80

Yet the beautiful is something more than the true presupposed by the good-more than the bonum apprehensum. It is characteristic of the beautiful that its apprehensio is taken as "appropriate and good" ("conveniens et bonum"). ${ }^{81}$ This knowledge of the beautiful must be a special type of knowledge. For the intellect apprehends things under the aspect of the true ("sub ratione veri"). ${ }^{82}$ Nevertheless, Thomas does not hold that the beautiful is the object of a distinct spiritual power. Nowhere does he distinguish, in addition to the cognitive and the appetitive, still a third power, a kind of aesthetic experience or intuition. How then is the knowledge of the beautiful to be interpreted?

Now there is a brief text in Thomas's commentary on the Sentences in which he posits a connection between knowledge and the good. There he distinguishes two grades in knowledge. In the first, intellective knowledge is directed toward the true; in the second, knowledge takes the true as conveniens and bonum. From such knowledge follow

79. Compare Summa theol. 1-2.19.3 ad 1.

8o. Summa theol. 1-2.27.2: "Bonum autem non est objectum appetitus, nisi prout est apprehensum. Et ideo amor requirit aliquam apprehensionem boni quod amatur. Et propter hoc... contemplatio spiritualis pulchritudinis vel bonitatis, est principium spiritualis amoris."

8I. Summa theol. 2-2.145.2 ad 1: "Objectum movens appetitum est bonum apprehensum. Quod autem in ipsa apprehensione apparet decorum, accipitur ut conveniens et bonum."

82. Summa theol. 1.82.4 ad 1: "sub ratione entis et veri, quam apprehendit intellectus." 
love and delight. ${ }^{83} \mathrm{With}$ respect to this second grade of knowledge, which we could call "affective," it is stated in another text in the same commentary that in it "the true is extended to the good" ("verum extenditur in bonum"). ${ }^{84}$ Because Thomas describes the apprehension of the beautiful in the same terms that he applies to the second grade of knowledge, this extension of the true to the good must be the place of the beautiful. The beautiful is the true taken as good. It pleases through its clarity and proportion.

We can find support for this interpretation in De pulchro et bono, which was long attributed to Thomas. It is in reality, however, a copy by Thomas of the lectures that his teacher Albert the Great had given in Cologne on pseudo-Dionysius's exposition of the beautiful. In question 1, article 1, Albert reflects on the order of the names Light, Beauty, and Love in chapter 4 of De divinis nominibus. This order must be understood according to the order of the processes in the mind. The first mental process is the apprehension of the true; next, the true incandesces (excandescit) and takes the character of good; this, finally, sets desire in motion, for desire is not moved unless directed by a prior apprehension. With these processes there corresponds, according to Albert, Dionysius's order of the names. With the apprehension of the true there corresponds light; with the apprehension of the true insofar as it has the character of the good ("apprehensioni autem veri secundum quod habet rationem boni") there corresponds the beautiful; with the movement of desire there corresponds love. ${ }^{85}$ In Albert's treatise one finds systematically elaborated what we discovered in Thomas only through a reconstructive interpretation of scattered texts. The place of the beautiful is the true taken as good.

Thomas's aesthetics is special in that he maintains the connection between the beautiful and the good even while he relates

83. Super Sent. 1.15.4.1 ad 3: "Videmus autem in cognitione duos gradus. Primum, secundum quod cognitio intellectiva tendit in unum [corrige: verum. Compare the text in the next note]. Secundum, prout verum accipit ut conveniens et bonum, et nisi sit aliqua resistentia ex tali cognitione, sequitur amor et delectatio." Compare Comp. theol. 1.165: "Ex apprehensione convenientis, delectatio generatur, sicut visus delectatur in pulchris coloribus."

84. Super Sent. 1.27.2.1: "Et quia potest esse duplex intuitus, vel veri simpliciter, vel ulterius secundum quod verum extenditur in bonum et conveniens."

85. The text of Albert's De pulchro et bono can be found in R. Busa, ed., S. Thomae Aquinatis Opera Omnia (Stuttgart: 1980), 7:43-47 (p. 43). 
the beautiful to knowledge, to the true. The beautiful is the object of contemplation. This relation to knowing comes to expression terminologically in many European languages. The German term for "beautiful," for example, schön, is cognate with the verb schauen, "to contemplate."

The beautiful is therefore related to the true and to the good. Its relatedness can be approached in two ways. Viewed from the Greek tradition and the perspective of pseudo-Dionysius, the beautiful is identical with the good; it adds to it conceptually a relation to knowledge. Regarded from Thomas's order of the transcendentals, the beautiful is to be taken as the extension of the true to the good. We can clarify this place of the beautiful further from the special relationship that exists between the true and the good.

These transcendentals occupy a distinct position in Thomas's exposition in De veritate 1.1 . The true and the good are relational transcendentals: they express the conformity of being with the two powers of the spiritual being, the cognitive and the appetitive. These powers extend to all that is. The formal objects of intellect and will, the true and the good respectively, manifest the infiniteness of the spirit. This must mean that the one formal object includes the other object in its infinite horizon. The true and the good include one another.

Thomas adduces this idea when he deals with the relation between theoretical and practical reason. They seem to be two distinct powers of the soul, since they have different formal objects. The object of the theoretical intellect is the true, and of the practical intellect, the good. The consequence of this must be that the theoretical intellect and the practical intellect are distinct powers, for the different ratio of the object differentiates the power. ${ }^{86}$

Still Thomas rejects this conclusion. The theoretical intellect and the practical intellect are not two distinct powers. The theoretical intellect itself becomes practical "by extension" (per extensionem). 87 That is possible because the objects of the theoretical intellect and of the practical intellect are related to each other in such a way that they confirm the unity of the two powers. "The true and the good include one another" ("se invicem includunt"). For the true is something that is good, else it would not be appetible; the good is something that is

86. Summa theol. 1.79 .11 ob. 2.

87. Summa theol. 1.79.11 sc. 
true, else it would not be intelligible. The object of the appetite may be the true, then, so far as it has the ratio of the good. That is the case, for example, when someone desires to know the truth. Conversely, the good can be the object of the intellect sub ratione veri. The practical intellect considers the good as practical, that is, as directed to a work. "The practical intellect knows truth, just as the theoretical intellect, but it directs the known truth to something that has to be done." The theoretical intellect becomes practical by extending the true to the good. ${ }^{88}$

The extension of the true to the good is also the place of the beautiful. Yet the beautiful is not the object of practical reason, for beauty is in the medieval view not a good that is to be made. Beauty does not belong to the domain of art but is primarily a property of things themselves. Yet there are clear analogies between the beautiful and the object of practical reason: the beautiful, too, is not the object of a distinct cognitive power, and the beautiful must be understood as the extension of the true to the good, an extension that is possible because the true and the good include one another.

From this determination of the beautiful it is possible, finally, to deduce why it does not acquire a separate place in the list of transcendentals. The beautiful is not for Thomas, as modern scholars suggest, a forgotten transcendental effecting a synthesis of the true and the good. The real situation is rather the reverse: the beautiful must be understood from the inclusion of the true in the good. The aesthetic is not in the Middle Ages an autonomous domain alongside the true and the good. The integration of the beautiful with other values did not need to be based on a distinct transcendental: it was implied in the transcendental order of truth and goodness.

Vrije Universiteit, Amsterdam

88. Summa theol. 1.79 .11 ad 2. Compare De verit. 3.3 ad 9. 